\title{
PROTECTIVE EFFECT OF SOME RENIN INHIBITORS IN ACUTE NEPHROTOXICITY INDUCED BY SOME ANTI-CARCINOGENIC DRUGS IN RATS
}

\author{
S. EL-Sherbini* G. R. EL-Sayed* and Shimmaa Ahmed** \\ Department of Biochemistry and chemistry of nutrition. \\ Veterinary Medicine, Mansoura University, Animal Health research institute
}

\begin{abstract}
Investigation was carried out to study protective effect of some renin inhibitors in acute nephrotoxicity on forty male Sprague Dawely rats weighting $200 \mathrm{~g}$ to $250 \mathrm{~g}$ which divided into four equal groups each group included 10 rats GroupI (Control group): was fed on normal ration for one month. While GroupII (cisplatin group) was injected i.p. by $7.5 \mathrm{mg} \mid \mathrm{kg} \mathrm{B.W}$ of cisplatin for one month. GroupIII (captopril group) was injected i.p. by $60 \mathrm{mg} \mid \mathrm{kgB}$.W of captopril for one month.GroupIV (captopril plus cisplatin group) there is injection of cisplatin $(7.5 \mathrm{mg} / \mathrm{kg} \mathrm{b} . w \mathrm{t})$ i.p and within one hour it is proceeded by i.p injection of captopril $(60 \mathrm{mg} / \mathrm{kg} \mathrm{b}$. wt) daily for one month. At the end of experiment the obtained results revealed that, administration of cisplatin and captopril caused a highly significant decrease in serum and kidney MDA, serum creatinine concentration, serum blood urea nitrogen concentration, serum angiotensin II concentration and serum aldosterone level. whole blood and kidney p53 concentration compared to cisplatin treated rats. Also there was highly significant increase in whole blood GSH concentration, serum Glutathione peroxidase, serum catalase activity, serum superoxide dismutase activity and serum renin concentration compared to cisplatin treated group. Administration of cisplatin only revealed in increase in serum and kidney MDA, serum creatinine concentration, serum blood urea nitrogen concentration, serum angiotensin II concentration serum aldosterone level, whole blood and kidney p53 concentration as compared to control group. There was a highly significant decrease in whole blood GSH concentration, serum Glutathione peroxidase, serum catalase activity, serum superoxide dismutase activity and serum renin concentration compared with control group. Administration of captopril only result in decrease in serum and kidney MDA, serum creatinine concentration, serum blood urea nitrogen concentration, serum angiotensin II concentration serum aldosterone concentration, whole blood and kidney p53 concentration compared to control group also there was highly significant increase in whole blood GSH concentration, serum Glutathione peroxidase, serum catalase activity, serum superoxide dismutase activity and serum renin concentration when compared to control group. These results were supported by histopathological examination which revealed some alterations represented by that the tubule was dilated and shrinked or atrophied, the tubular cells was removed and lost and there is asignificant destruction of glomerular with penetration of leuococyte and intratubular bleeding. While administration of cisplatin and captopril result in regenerating glomeruli and tubules of kidney tissues produce by cisplatin administration.
\end{abstract}

\section{INTRODUCTION}

One of the features of Cislplatin is antitumor drug,so it isneeded for curing of several types of cancers (Lebwohl and Canetta, 1998 and Alderden et al., 2006). It is reported that several enzymes including catalase, superoxide dismutase, glutathione peroxidaseis lowered also there is lowering in the concentration of reduced glutathione. On the other hand, there is amarkedly increasing in nitric oxide and malondialdehyde therefore, cisplatin has the ability to enhance the concentration of blood urea nitrogen and with adepletion of glomerular filtration rate (Cetin et al., 2006). Mai et al., (1983) indicated that 
renin has both enzymatic and hormonal property, acute renal failure occurs through priciptation of cisplatin in the left and right kidneys which happens due to conversion of angiotensinogen into angiotensin $I$ in the prescence of renin this accompanied by formation of angiotensin II which in turn has the ability to secrete aldosterone hormone (Okui et al., 2012).

Both of angiotensin converting enzyme and angiotensin II are elevated markedly by cisplatin in beagle dogs therefore, endothelial damage occurs due to high concentration of angiotensin II, (Cubeddu et al., 1990and Marvaala et al., 2001). Price et al., (2004), generally, kidney failure and degeneration of tissue is mainly due to deposition and accumulation of p53 in kidney especially the outer medulla by cisplatin (Wei et al., 2007).

Due to involvement of p53 in renal failure induced by cisplatin so the kidneys protection occurs through suppression of p53 (Gudkov and Komarova, 2005).

Hypetension and left sided congestive heart failure are medicated by captopril which it is one of angiotensin converting enzyme inhibitor (Akif et al., 2010).

Schoneich et al., (1990) proved that oxidation reactions are prevented by captopril due to its role as antioxidant and free radical removal.

In renal tissue, malondialdhyde levels are declined by Captopril (Mansour et al., 1999). Captopril intake suppress the elevation of both blood urea nitrogen and creatinine in the blood (Krishan et al., 1998). Renin concentration is increased due to stoppage of renin angiotensin system by captopril therapy (Azizi et al., 2004).

Morrissey et al., (1996) captopril inhibit proliferating cell nuclear antigen by suppressing the p53 gene expression.
The purpose of this study is aimed to find out the role of captopril in prevention of renal toxicity caused by cisplatin so as to lessen the harmful effect of aldosterone, angiotensinII, and other lipid peroxides.

\section{MATERIAL AND METHOD}

\section{Experimental design:}

\section{Animals grouping:}

Inorder to establish the aim of the work of this experiment forty male Sprague Dawely rats weighting( $200 \mathrm{~g}$ to $250 \mathrm{~g}$ ) were divided into four equal groups (each of 10 rats). GroupI (Control group): was supplied with normal control diet according to NRC, (1995) for one month. While GroupII (cisplatin group) was injected i.p. by $7.5 \mathrm{mg} \backslash \mathrm{kgB}$.W of cisplatin for one month.GroupIII (captopril group) was injected i.p. by $60 \mathrm{mg} \backslash \mathrm{kgB}$.W of captopril for one month.GroupIV (captopril plus cisplatin group) there is injection of cisplatin $(7.5 \mathrm{mg} / \mathrm{kg}$ b .wt) i.p and within one hour it is proceeded by i.p injection of captopril $(60 \mathrm{mg} / \mathrm{kg}$ b. wt) daily for one month. Administration of $60 \mathrm{mg} / \mathrm{kg} \mathrm{B.W}$ of captopril i.p. according to Mansour et al., (1999). Also cisplatin is administrated i.p. $7.5 \mathrm{mg} / \mathrm{kgB}$.W according to Uehara et al., (2005); Mansour et al., (2006) .At the end of experiment, blood samples were collected from the heart of the rats. Thiopental sodium was used as anaesthetic agent for rats by adose $50 \mathrm{mg} / \mathrm{kgB}$.W which was dissolved in $5 \mathrm{ml}$ distilled water and administrated intraperitoneally in rats according to the method of Singh and Boyd, (1966). Blood samples was collected for determination of reduced glutathione concentration in whole blood (Beutler et al., 1963),serum Glutathione Peroxidase (Pagliam and Valentine, 1967), serum Catalase activity( Aebi, 1984), serum superoxide 
dismutase activity(Nishikimi et al., 1972), Serum Malondialdehyde (Draper and Hadley, 1990), Serum creatinine concentration(Murry and Kaplan ,1984), serum blood urea nitrogen concentration (Kaplan, 1984), Serum renin concentration was determined by ELIZA (Müller and luft, 2006), serum angiotensin II concentration was determined by ELIZA (Porstmann and Kiessig , 1992) serum aldosterone concentration was determined by ELIZA (Thomas, 2005), whole blood and kidney p53 gene was determined by semi quantitative real time PCR (Miyajima et al .,
2001). At the end of experiment rats were dissected to obtain kidney,wich then divided longitudinally into two equal parts . The First part of the kidney was kept in phosphate buffer saline and used for determination of kidney Malondialdehyde (Yoshioka et al., 1982). The second part was kept in $20 \%$ formalin for histopathology examination using Hematoxylin and Eosin (Woods and Ellis, 1994).

Statistical analyses were performed according to Steel and Torrie, (1960).

Table (1): Effect of captopril and cisplatin injection on whole blood and serum biochemical parameters and enzyme activities of rats. (Mean \pm S.E) $n=10$

\begin{tabular}{|l|l|c|c|c|c|c|}
\hline Groups & $\begin{array}{c}\text { Reduced } \\
\text { glutathione } \\
(\mathbf{m g} / \mathbf{d l})\end{array}$ & $\begin{array}{c}\text { Glutathione } \\
\text { peroxidase } \\
(\mathbf{m u} / \mathbf{m l})\end{array}$ & $\begin{array}{c}\text { Catalase } \\
\text { activity } \\
\mathbf{( U / L )}\end{array}$ & $\begin{array}{c}\text { Superoxide } \\
\text { Dismutase } \\
\text { activity } \\
\mathbf{( U / m )}\end{array}$ & $\begin{array}{c}\text { MDA } \\
(\mathbf{n m o l} / \mathbf{L})\end{array}$ & $\begin{array}{c}\text { Kidney } \\
\text { MDA } \\
(\mathbf{n m o l} / \mathbf{g r a m} \\
\text { tissue) }\end{array}$ \\
\hline Group I & $54.85 \pm 0.82^{\mathrm{b}}$ & $1424.43 \pm 8.2^{\mathrm{b}}$ & $3.26 \pm 0.08^{\mathrm{b}}$ & $820 \pm 2.5^{\mathrm{b}}$ & $0.98 \pm 0.03^{\mathrm{b}}$ & $2.12 \pm 0.06^{\mathrm{c}}$ \\
\hline Group II & $23.99 \pm 0.78^{\mathrm{d}}$ & $330.61 \pm 3.89^{\mathrm{d}}$ & $0.711 \pm 0.02^{\mathrm{d}}$ & $448.7 \pm 1.8^{\mathrm{d}}$ & $4.87 \pm 0.08^{\mathrm{a}}$ & $10.74 \pm 0.20^{\mathrm{a}}$ \\
\hline Group III & $66.01 \pm 0.99^{\mathrm{a}}$ & $1610.95 \pm 4.84^{\mathrm{a}}$ & $4.06 \pm 0.09^{\mathrm{a}}$ & $942 \pm 4.5^{\mathrm{a}}$ & $0.68 \pm 0.01^{\mathrm{b}}$ & $1.33 \pm 0.04^{\mathrm{d}}$ \\
\hline Group IV & $37.8 \pm 0.97^{\mathrm{c}}$ & $844.65 \pm 2.3^{\mathrm{c}}$ & $1.42 \pm 0.07^{\mathrm{c}}$ & $597 \pm 5.03^{\mathrm{c}}$ & $2.39 \pm 0.07^{\mathrm{c}}$ & $6.19 \pm 0.10^{\mathrm{b}}$ \\
\hline
\end{tabular}

- Means carries the same superscript letter are considered non significant,while the means carries the different superscript letter are considered significant.

Table (2): Effect of captopril and cisplatin injection Serum creatinine,urea,angiotensin and aldosterone level of rats. (Mean \pm S.E) $n=10$

\begin{tabular}{|l|c|c|c|c|c|}
\hline \multicolumn{1}{|c|}{ Groups } & $\begin{array}{c}\text { creatinine } \\
(\mathbf{m o l} / \mathbf{L})\end{array}$ & $\begin{array}{c}\text { blood urea } \\
\text { nitrogen } \\
(\mathbf{m g} / \mathbf{d l})\end{array}$ & $\begin{array}{c}\text { renin } \\
\text { concentration } \\
(\mathbf{p g} / \mathbf{m L})\end{array}$ & $\begin{array}{c}\text { angiotensin II } \\
\text { concentration } \\
(\mathbf{n g} / \mathbf{m l})\end{array}$ & $\begin{array}{c}\text { aldosterone } \\
\text { concentration } \\
(\mathbf{p g} / \mathbf{m L} \mathbf{)}\end{array}$ \\
\hline Group I & $0.67 \pm 0.04^{\mathrm{c}}$ & $25 \pm 0.93^{\mathrm{c}}$ & $27.08 \pm 0.30^{\mathrm{b}}$ & $476.5 \pm 3.5^{\mathrm{c}}$ & $140 \pm 0.85^{\mathrm{d}}$ \\
\hline Group II & $3.17 \pm 0.09^{\mathrm{a}}$ & $71 \pm 0.80^{\mathrm{a}}$ & $17.57 \pm 1.32^{\mathrm{d}}$ & $548.8 \pm 3.8^{\mathrm{a}}$ & $574 \pm 10^{\mathrm{a}}$ \\
\hline Group III & $0.65 \pm 0.03^{\mathrm{c}}$ & $25 \pm 0.85^{\mathrm{c}}$ & $32.7 \pm 0.64^{\mathrm{a}}$ & $427.2 \pm 2.9^{\mathrm{d}}$ & $106 \pm 1.3^{\mathrm{b}}$ \\
\hline Group IV & $2.2 \pm 0.08^{\mathrm{b}}$ & $55 \pm 0.81^{\mathrm{b}}$ & $20.5 \pm 0.36^{\mathrm{c}}$ & $513 \pm 2.9^{\mathrm{b}}$ & $316 \pm 13.8^{\mathrm{c}}$ \\
\hline
\end{tabular}


Table (3): Effect of captopril and cisplatin injection on whole blood and kidney p53

\begin{tabular}{|c|c|}
\hline $\begin{array}{c}\text { whole blood } \\
\text { p53 }\end{array}$ & kidney p53 \\
\hline $0.004 \pm 0.001^{\mathrm{a}}$ & $0.01 \pm 0.001^{\mathrm{a}}$ \\
\hline $0.042 \pm 0.0036^{\mathrm{b}}$ & $0.1 \pm 0.01^{\mathrm{b}}$ \\
\hline $0.001 \pm 0.0004^{\mathrm{d}}$ & $0.005 \pm 0.0004^{\mathrm{d}}$ \\
\hline $0.014 \pm 0.002^{\mathrm{c}}$ & $0.04 \pm 0.003^{\mathrm{c}}$ \\
\hline
\end{tabular}
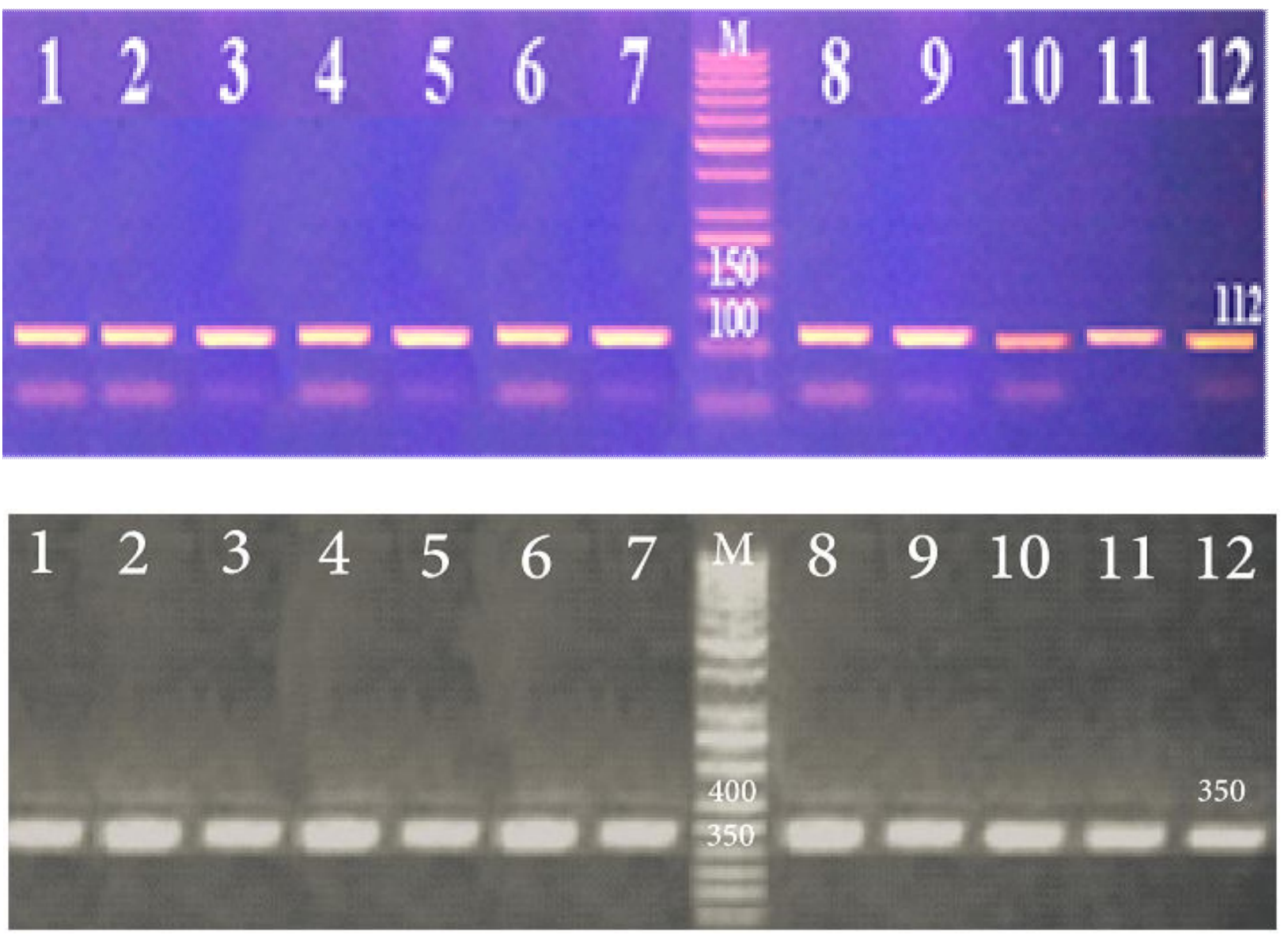

Fig.(1): Semiquantitative RT-PCR of blood tumor protein p53 against $\beta$ actin as housekeeping gene, where the amplified segement of blood tumor protein p53 gene expression was at $112 \mathrm{bp}$, while the amplified segment of $\beta$ actin gene expression was at 350 bp against DNA ladder (M) ranged from $50 \mathrm{bp}$ to $1500 \mathrm{bp}$. Lan $(1,2 \& 3)$ represented Group I. Lane $(4,5,6)$ represented Group II. Lane (7, $8 \& 9)$ represented Group III. Lane (10, 11, and 12) represented Group IV. 

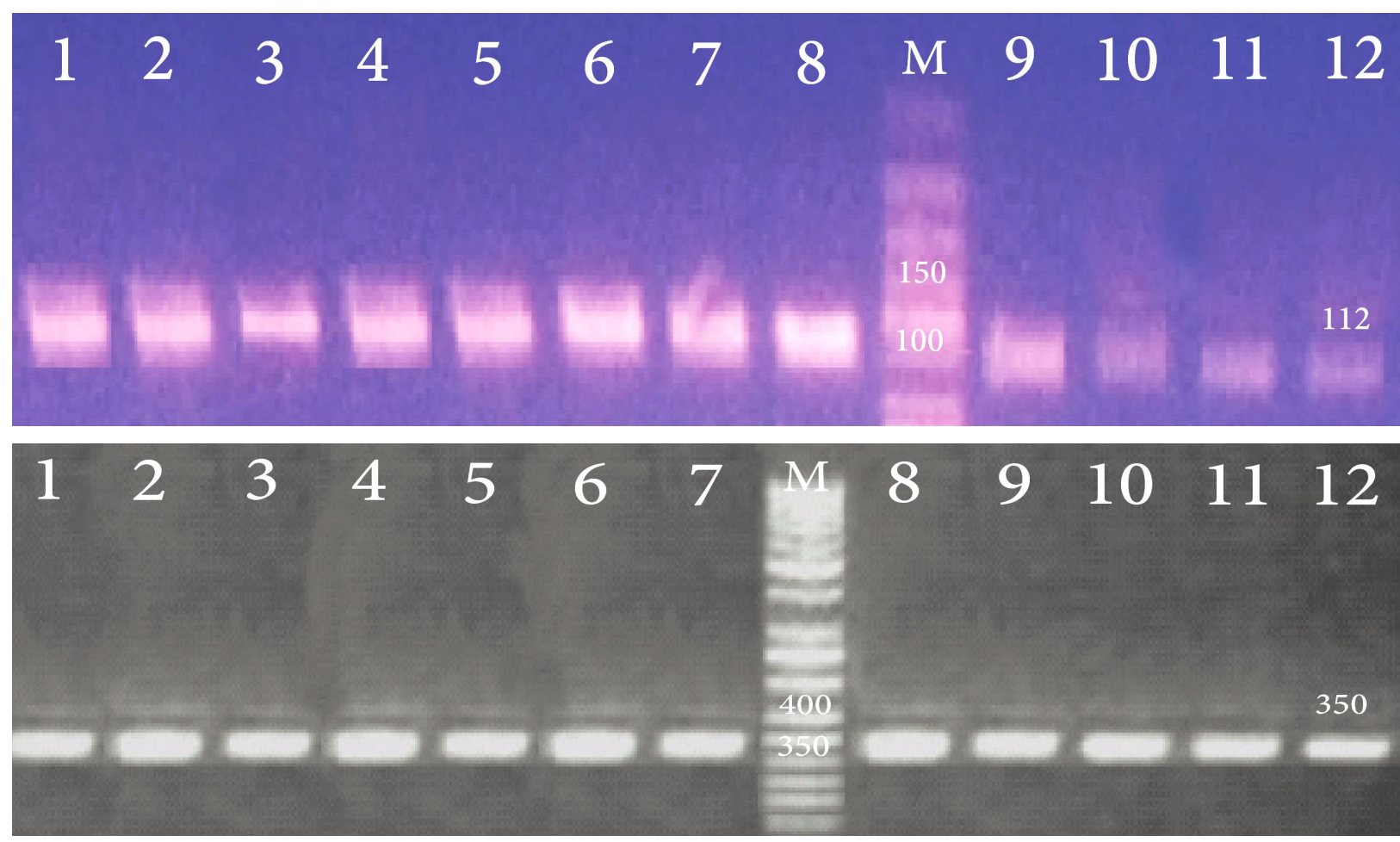

Fig. (2): Semi-quantitative RT-PCR of kidney tumor protein p53 against kidney $\beta$ actin as housekeeping gene, where the amplified segement of kidney tumor protein p53 gene expression was at $112 \mathrm{bp}$, while the amplified segment of kidney $\beta$ actin gene expression was at $350 \mathrm{bp}$ against DNA ladder (M) ranged from $50 \mathrm{bp}$ to $1500 \mathrm{bp}$. Lan $(1,2 \& 3)$ represented Group I. Lane $(4,5,6)$ represented Group II. Lane $(7,8 \& 9)$ represented Group III. Lane $(10,11,12)$ represented Group IV.

\section{Histopathological examination of kidney}

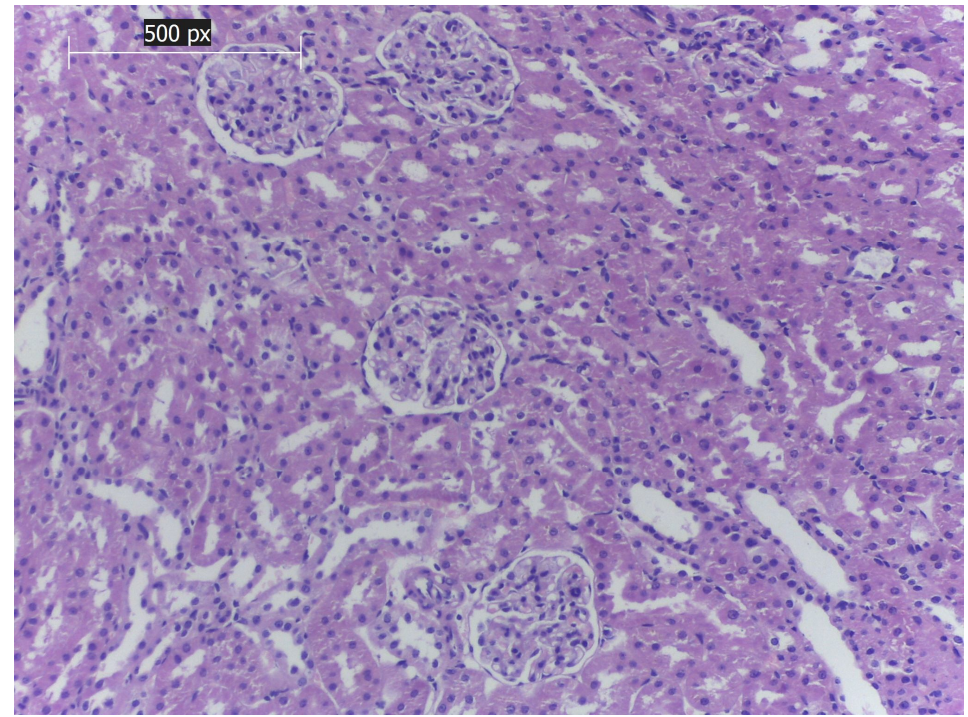

Fig.(3): Control group, showing normal structure of the glomerulus, Bowman's capsule, proximal tubules and distal tubules. (10x, H\&E). 


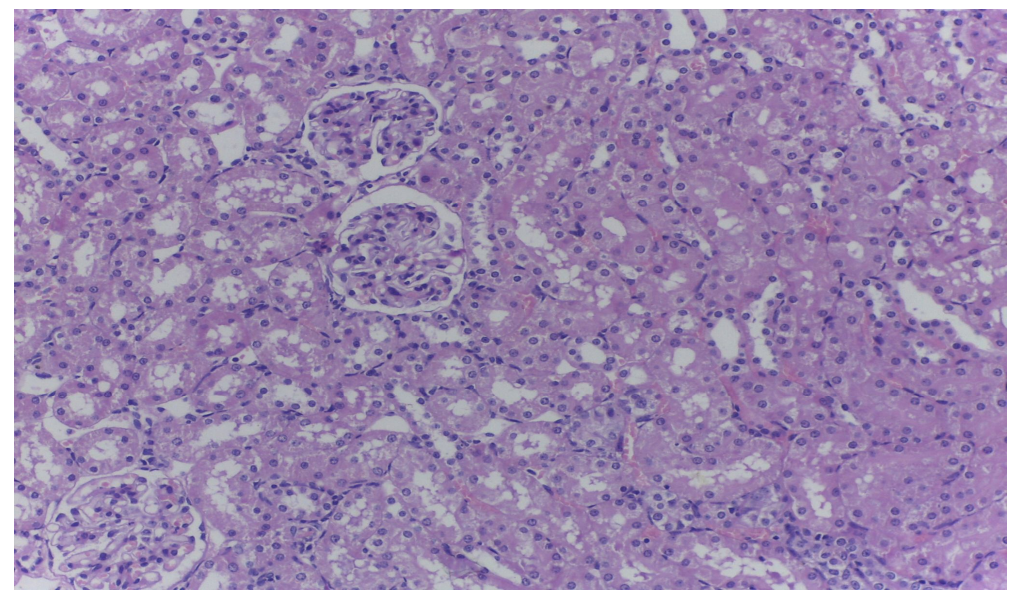

Fig.(4): Captopril group, showing normal structure of the glomerulus, Bowman's capsule, proximal tubules and distal tubules. (10x, H\&E).

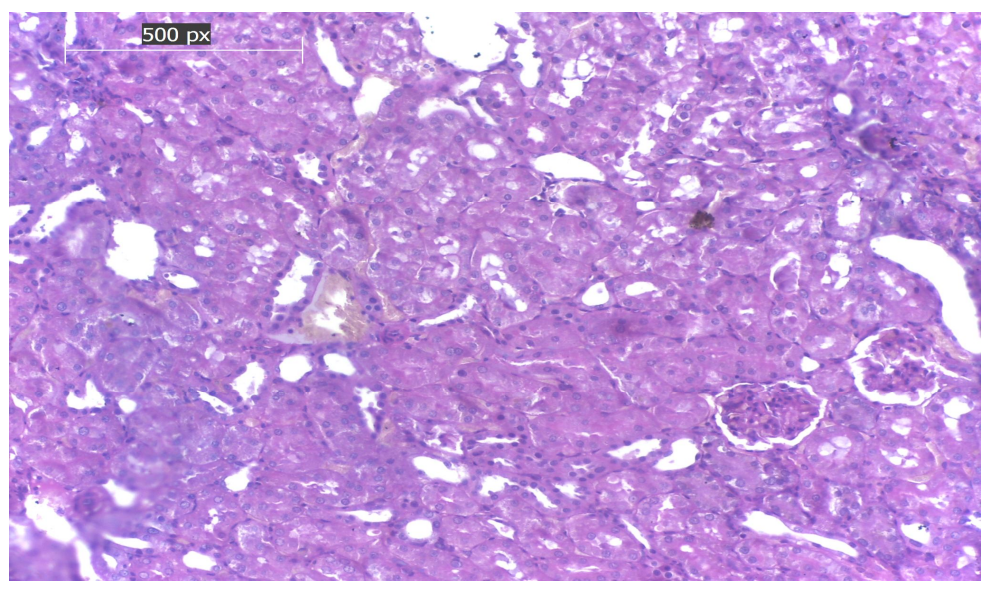

Fig.(5):Cisplatin group, showing glomerular degeneration with tubular dilation and atrophy with sheded tubular cells, intratubular hemorrhage and leuococytic infiltration.

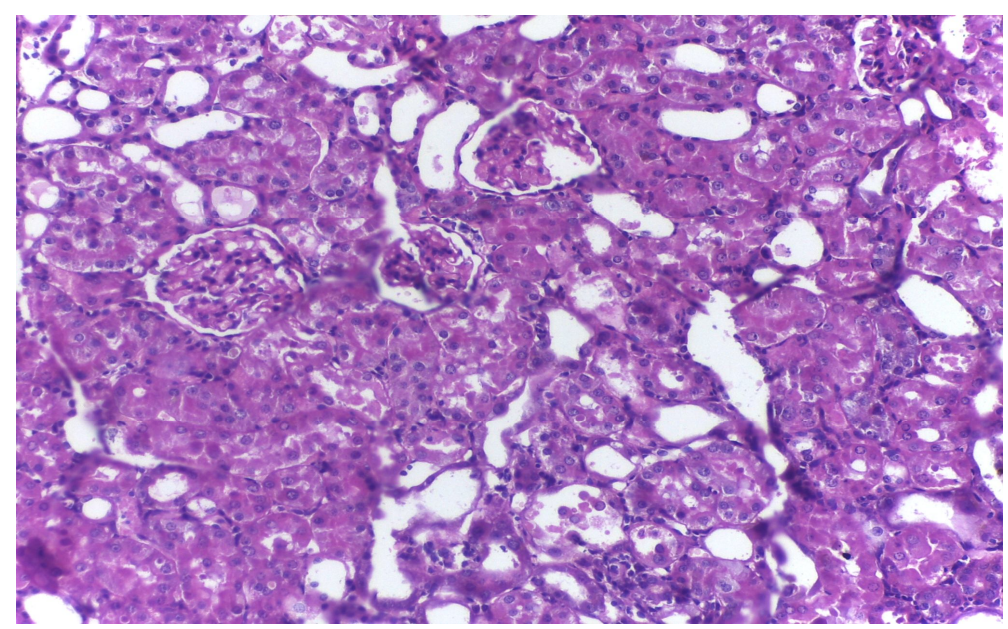

Fig.(6): Mixed group, exhibit that there was regenerating glomeruli and tubules. 


\section{RESULTS AND DISCUSSION}

In Table(1), Injection of cisplatin (7.5 $\mathrm{mg} / \mathrm{kg} \mathrm{B.W)}$ interperitoneally in normal rats caused a significant decrease in whole blood reduced Glutathione, serum Glutathione peroxidase,serum catalase and serum superoxide dismutase and a significant increase in serum and kidney MDA when compared with control group. These results agree with the findings of Silva et al., (2001) who recorded a significant depletion in renal GSH level after interperitoneal administration of cisplatin $(7.5 \mathrm{mg} / \mathrm{kgB}$.Wt). It has been indicated that cisplatin is able to inhibit the activity of antioxidant enzymes such as CAT, SOD, GPx and generate reactive oxygen species in renal tissue ( Noori and Mahboobc, 2010). Cisplatin has the ability to induce nephrotoxicity, this usually occur through reducing activities of enzymatic antioxidants including SOD and catalase (El-Beshbishy et al., 2011). Cisplatin administration in rats caused a reduction in serum reduced glutathione levels and an elevation in the concentrations of serum and tissue MDA (Chirino and Pedraza-Chaverri , 2009).

Administration of captopril $(60 \mathrm{mg} / \mathrm{kg})$ interperitoneally induced a significant increase in whole blood reduced Glutathione, serum Glutathione peroxidase, serum catalase and serum superoxide dismutase and a significant decrease in serum and kidney MDA compared to control group. While in cisplatin and captopril-treated rats, the tested drugs caused a highly significant increase in whole blood reduced Glutathione, serum Glutathione peroxidase, serum catalase and serum superoxide dismutase and a significant decrease in serum and kidney MDA compared to cisplatin treated group, It is indicated that when animals were treated with captopril before cisplatin administration, the GSH is significantly increased. In erythrocytes and brain, captopril has been found to increase GSH content (DeCavanagh et al., 2000). It is reported that the antioxidant effects of captopril against cisplatin-induced nephrotoxicity are in agreement with those of Kalia et al., (2007). Enalapril and captopril treatments have the ability to increase both the activities of SOD and Se-GPx (Groner et al., 1992). Captopril was found to decrease MDA levels and increase the GSH levels, this followed by induction of angiotensin II which has the ability through the membrane bound $\mathrm{NADH} / \mathrm{NADPH}$ oxidase to increase the generation of ROS, so, the level of angiotensin II is decrease by ACEIs followed by a significant decreasing the ROS production which finally produces a decrease in MDA production and decrease in GSH activity (Uzunova et al., 2005).

In Table (2), administration of cisplatin (7.5 $\mathrm{mg} / \mathrm{kg} \mathrm{B.W}$ ) interperitoneally in rats caused a significant increase in serum creatinine, blood urea nitrogen, angiotensin and aldosterone levels and a significant decrease in serum renin when compared with control group. These results agree with the findings of Ugur et al., (2015) high concentration of creatinine and urea in serum induced by cisplatin. Both of angiotensin converting enzyme and angiotensin II are elevated markedly by cisplatin in beagle dogs therefore endothelial damage occurs due to high concentration of angiotensin II (Taskin et 
al., 2014). Priciptation of cisplatin in the left and right kidneys due to conversion of angiotensinogen into angiotensin $I$ in the prescence of renin this accompanied by formation of angiotensin II which in turn has the ability to secrete aldosterone hormone leading to acute renal failure (Okui et al., 2012). The increased release of angiotensin II due to increase the renin level than AngII reacts with AT1 receptors in the CJG. leads to the inhibition of renin secretion occur through these binding which is known as short feedback loop (Chan et al.; 2000).

Administration of captopril $60 \mathrm{mg} / \mathrm{kg}$ interperitoneally evoked a significant decrease in serum creatinine, blood urea nitrogen, angiotensin and aldosterone levels and a significant increase in serum renin when compared to control group. While in cisplatin and captopril-treated rats induced a highly significant decrease in serum creatinine, blood urea nitrogen, angiotensin and aldosterone levels and a significant increase in serum renin compared to control group. These results agree with the findings of Deng et al. (2001) who indicated that attenuation of oxidative stress, ROS-NO interaction and NO production by captopril, occur through decreasing of angiotensin II which lead to a signficant decrease in aldosterone. Treatment of hyper tension due to stimulation of renin release by both renin and ACE inhibitors. (Duncan et al., 2009). ACE and renin inhibitors suppress the activity of AT1 receptor that lead to blocking the negative feedback of renin release which accompanied by increasing the blood renin concentration Staessen et al., 2006).
In Table (3), administration of cisplatin at $7.5 \mathrm{mg} / \mathrm{kg} \mathrm{B.W}$ interperitoneally in rats caused a significant increase in whole blood and kidney tissue p53 gene expression when compared with control group. These results agree with the findings of Wei et al.,(2007) who found that cisplatin treatment activates p53 in kidney in vivo and p53 phosphorylation and accumulation is induced by cisplatin mainly in the outer medulla of the kidneys and cell nuclei of cortex, resulting in renal dysfunction and tissue damage in mice. Price et al., (2004), reported that in response to cisplatin treatment, there is a rapid nuclear deposition of p53 in the outer medulla of the kidney.

Administration of captopril $60 \mathrm{mg} / \mathrm{kg}$ interperitoneally caused a significant decrease in whole blood and kidney tissue p53 gene expression compared to normal rats. While in cisplatin and captopril-treated rats caused a highly significant decrease in whole blood and kidney tissue p53 gene expression when compared to control group. It was reported that captopril and other ACE inhibitors inhibit the expression of p53( Ziori et al., 2006). On the other hand Kossmehl et al., (2006), ACE inhibitors inhibit proliferating cell nuclear antigen by suppressing the elevation of p53 gene expression.

Histopathological examination of kidney showing In Control group, showing normal structure of the glomerulus, Bowman's capsule, proximal tubules and distal tubules. (10x, H\&E). while in captopril group , Administration of captopril $60 \mathrm{mg} / \mathrm{kg}$ interperitoneally showing normal structure of the glomerulus, Bowman's capsule, proximal and distal tubules. (10x, H\&E). therefore in 
cisplatin group, administration of cisplatin at $7.5 \mathrm{mg} / \mathrm{kg} \mathrm{B}$.W interperitoneally in rats that the tubule was dilated and shrinked or atrophied, the tubular cells was removed and lost and there is asignificant destruction of glomerular with penetration of leuococyte and intratubular bleeding. These in agree with(Antunes et al., 2000) that, after CP injection in rats there is a significant increase in BUN and creatinine in serum and histopathological changes including protein casts vacuolation and necrosis were observed in proximal renal tubules on the second day. Also there is a significantly elevation in urea and plasma creatinine values, therefore there is extreme tubular damage in renal failure rats (Zhou et al., 2006). It is reported that the DNA damage is induced by p53 as degeneration of DNA has been identified as the major cause of cell injury and death during cisplatin chemotherapy (Megyesi et al., 1996 andCepeda et al., 2007). whrease in mixed group,administration of captopril $60 \mathrm{mg} / \mathrm{kg}$ interperitoneally and administration of cisplatin at $7.5 \mathrm{mg} / \mathrm{kg} \mathrm{B} . \mathrm{W}$ interperitoneally in rats exhibit that there was regenerating glomeruli and tubules.this agree with (ElSayed et al., 2008) who discuss that nephrotoxicity caused by cisplatin is treated by captopril because it has the ability to erase the free radical and has antioxidant activity. captopril inhibite the concentration of angiotensin II in rats with high blood pressure, so the oxidant stress reduce the abbility of captopril in lowering the blood pressure (Bolterman et al., 2005). Furthermore, the expression of p53 is suppressed by ACE inhibitors (Ziori et al., 2006).

\section{REFERENCES}

Aebi, H. (1984): Colorimetric determination of Catalase in plasma. Methods Enzymol, 105:121-126.

Akif, M.; Georgiadis, D.; Mahajan, A.; Dive, V.; Sturrock, E. D.; Isaac, R. E.and Acharya, K. R. (2010): "HighResolution Crystal Structures of Drosophila melanogaster AngiotensinConverting Enzyme in Complex with Novel Inhibitors and Antihypertensive Drugs". Journal of Molecular Biology, 400 (3): 502-517.

Alderden, R.A.; Hall, M.D. and Hambley, T.W. (2006): The Discovery and Development of Cisplatin. J. Chem. Education., Vol.83, No.5, pp. 728-734.

Antunes, L.M.G.; DArin, J.D.C.andBianchi, M.L.P. (2000): Protective effects of vitamin $\mathrm{C}$ against cisplatin-induced nephrotoxicity and lipid peroxidation in adult rats: adose-dependent study.Pharmacol.Res.41, 405-411.

Azizi, M.; Bissery, A.; Lamarre-Cliché, M.and Me'nard, J. (2004): Integrating drug Pharmacokinetics for phenol typing individual renin response to angiotensinII blockade in humans. Hypertension, 43:785-790.

Beutler, E.; Duron, $O$ and Kelly, M.B. (1963):J.Lab Clin.Med.61, 882.

Bolterman, R.J.; Manriquez, M.C.; Ruiz, M.C.; Juncos, L.A, and Romero JC. (2005): Effects of Captopril on the Renin Angiotensin System, Oxidative Stress, and Endothelin in Normal and 
Hypertensive Rats. Hypertension, 46:934-947.

Cepeda, V.; Fuertes, MA.; Castilla, J.; Alonso, C.; Quevedo, C.; Pérez, JM. (2007): Biochemical mechanisms of cisplatin cytotoxicity. Anticancer Agents Med Chem 7: 3-18.

Cetin, R.; devrim, E.; Kilicogula, B.; Avci, A.; Candir, O. and Durak, I. (2006): Cisplatin impairs antioxidant system and causes oxidation in rat kidney tissues: possible protective roles of natural antioxidant foods. J. Appl. Toxicol., 26(1): 42-46.

Chan, W.P.; Fung, M.L.; Nobiling, R. and Leung, P.S. (2000): Activation of local renin- angiotensin system by chronic hypoxia. Molec Cell Endocrinol. 160:107-14

Chirino, YI and Pedraza-Chaverri, J. (2009): Role of oxidative and nitrosative stress in cisplatin-induced nephrotoxicity .Experimental and toxicologic pathology: official journal of the Gesellschaft fur Toxikologische Pathologie 61,223-242.

Cubeddu L.X., Hoffmann I.S., Fuenmayor N.T. and Finn, A.L.( 1990): Efficacy of ondansetron and the role of serotonin in cisplatin-induced nausea and vomiting. N. Engl. J. Med.; 322:810-816.

DE Cavanagh, E.M.; Inserra, F.; Ferder, L. and Fraga, C.G. (2000): Enalapril and captopril enhance glutathionedependent antioxidant defense in mouse tissues. Am. J. Physiol. Regul. Integr. Comp. Physiol., 278: R572R577.
Deng G.; Vaziri, ND.; Jabbari, B.; Ni, Z .and Yan, XX. (2001): Increased tyrosine nitration of the brain in chronic renal insufficiency: reversal by antioxidant therapy and angiotensinconverting enzyme inhibition. J. Am. Soc Nephrol, 12: 1892-1899.

Draper, H.H. and Hadley, M. (1990): Malondialdehyde determination as index of lipid peroxidation. Methode.Enzymol, 186:421-431.

Duncan, J.; Campbell. And Senior Research Fellow, St. (2009): Renin inhibitors mechanisms of action Vincent's Institute of Medical Research and Department of Medicine, University of Melbourne, St Vincent's Hospital, MelbourneAust Prescr, 32:132-5.

El-Beshbishy, H.A.; Bahashwan, S.A.; Aly, H.A.and Fakher, H.A. (2011): Abrogation of cisplatin-induced nephrotoxicity in mice by alpha lipoic acid through ameliorating oxidative stress and enhancing gene expression of antioxidant enzymes. Eur J Pharmacol; 668: 278-284.

El-Sayed, el-SM1.; Abd-Ellah, M.F.and Attia, S.M. (2008): Protective effect of captopril against cisplatin-induced nephrotoxicity in rats. Pak $\mathrm{J}$ Pharm Sci.; 21(3):255-61.

Groner, Y.; Elroy-Stein, O.; Avraham, K. B.; Schickler, M.; Knobler, H.; Minc-Golomb， D.; Bar-Peled, O.; Yarom, R. and Rotshenker, S. (1992) : Current Communications in Cell and Molecular Biology 5, Molecular Biology and Free Radical Scavenging Systems (Scandalios, J.G. Ed.) Cold Spring Harbor Laboratory 
Press, Cold Spring Harbor, pp. 263280.

Gudkov, AV.and Komarova, EA. (2005): Prospective therapeutic applications of p53 inhibitors. Biochem Biophys Res Commun.;331:726-736.

Kalia, K.; Narula, G.D.;Kannan, G.M. and Flora, S.J. (2007): Effects of combined administration of captopril and DMSA on arsenite induced oxidative stress and blood and tissue arsenic concentration in rats. Comp. Biochem. Physiol. C. Toxicol. Pharmacol., 144(4): 372- 379.

Kaplan, A. (1984): Clin Chem The C.V.Mosby Co.St Louis.Toronto.Prnceton, 1257-1260 and 437,418 .

Kossmehl ,P1.; Kurth, E.; Faramarzi, S.; Habighorst ,B.; Shakibaei, M.; Wehland, M.; Kreutz, R.; Infanger, M. J.; Danser, A.H.; Grosse ,J.; Paul, M.and Grimm, D.(2006): Mechanisms of apoptosis after ischemia and reperfusion: role of the renin-angiotensin system Apoptosis, 11 (3): $347-58$.

Krishan, P1.; Sharma, A. and Singh, M. (1998): Effect of angiotensin converting enzyme inhibitors on ischaemia-reperfusion-induced renal injury in rats. Pharmacol .Res. 37(1):23-9.

Lebwohl, D1 and Canetta, R.(1998): Clinical development of platinum complexes in cancer therapy: an historical perspective and an update. Eur J Cancer. 1998 Sep; 34(10):1522-34.
Marvaala, E.M.A.; Cheng, Z.J.; Tikkanen, I.; Lapatto, R.; Nurminen, K.; Vapaatalo, H.; Müller, D.N.; Fiebeler, A.; Ganten, U.; Ganten, D. and Luft, F.C. (2001): Endothelial dysfunction and Xanthine oxidoreductase activity in rats with human renin and angiotensinogen genes. Hypertension, 37(2): 414-422.

Mai,T.; Miyazaki, H.; Hirose, S.; Hori, H.; Hayashi, T.; Kageyama, R.; Ohkubo, H.; Nakanishi, S. and Murakami, K. (1983): "Cloning and sequence analysis of cDNA for human renin precursor". Proceedings of the National Academy of Sciences U.S.A, 80 (24): 7405-9.

Mansour, MA.; El-Kashef, HA.and AlShabanah, OA. (1999): Effect of captopril on doxorubicin-induced. nephrotoxicity in normal rats. Pharmacol. Res, 39(3); 233-237.

Mansour, H.H.; Hafez, H.F. and Fahmy, N.M. (2006): Silymarin modulates cisplatin-induced oxidative stress and hepatotoxicity in rats. J. Biochem. Mol. Biol, 39(6):656-661.

Megyesi, J.; Udvarhelyi, N.; Safirstein, RL.; and Price, PM. (1996): The p53independent activation of transcription of p21 WAF1/CIP1/SDI after acute renal failure. Am J Physiol ,271: F1211-F1216.

Miyajima, K1.; Tamiya, S.; Oda, Y.; Adachi, T.; Konomoto, T.; Toyoshiba, H.; Masuda, K.;Tsuneyoshi, M.(2001): Relative quantitation of p53 and MDM2 gene expression in leiomyosarcoma; realtime semi-quantitative reverse 
transcription-polymerase

chain reaction. Cancer Lett. 164(2):177-88.

Morrissey, J.J1.; Ishidoya, S.; McCracken, R.and Klahr, S. (1996): Control of p53 and p21 (WAF1) expression during unilateral ureteral obstruction Kidney Int Suppl, 57:S84-92.

Müller, D.N. and Luft, F.C. (2006): Direct renin inhibition with aliskiren in hypertension and target organ damage. Clin J Am Soc Nephrol. 1, 221-8.

Murray, R.L and Kaplan, A. (1984): Creatinine.Clin Chem the C.V.Mosby Co.St Louis.Toronto, Princeton. 1261-1266 and 418.

Nishikimi, M.; Roa, H.A.and Yogi. 1972): Biochem.Bioph.Res.Common., 46:849854.

Noori, S. and T. Mahboobc. (2010): Antioxidant effect of carnosine pretreatment on cisplatin-induced renal oxidative stress in rats. Ind. J. Clin. Biochem ‘.25: 86-91.

NRC. (1995): Nutrient requirement for laboratory animals. Fourth revised edition. National Academy Press Washington, D.C; National Research Council.

Okui, S.;Yamamoto, H.;Li,W.; Gamachi, N.; Fujita, Y.;Kashiwamura, S.; Miura, D.;Takai, S.;Miyazaki, M.;Urade, M.; Okamura, H.and Ueda, H. (2012): Cisplatin-induced acute renal failure in mice is mediated by chymase-activated angiotensinaldosterone system and interleukin18.Eur J Pharmacol,15; 685(1-3):14955.
Pagliam, D.E. and Valentine, W.N. (1967): Glutathione Peroxidase determined in plasma by UV methode.J Lab.Clin.Med.70:158-169.

Price, PM.; Safirstein, RL.; and Megyesi, J. (2004): Protection of renal cells from cisplatin toxicity by cell cycle inhibitors. Am. J. Physiol. Renal. Physiol .,286: F378-F384.

Porstmann, T. and Kiessig, S.T. (1992): Enzyme Immunoassay Techniques, an Overview, Journal of Immunological Methods, 150 5-21.

Schoneich, Ch.; Dilinger, U.; VonBruchhausen, f.and Asmus, K.U. (1990): Antioxidant effect of captopril Archive.Biochem. and Bioph.65, 7.

Silva, C.R.; Greggi Antunes, L.M. and Bianchi, M. (2001): Antioxidant action of bixin against cisplatin-induced chromosome aberrations and lipid peroxidation in rats. Pharmacol. Res., 43: 561-566.

Singh, J.and Boyd, E.M. (1966): Thiopental Anesthesia and Tannic acid Diagnostic Enemas.Canad.Med.Ass, 95:558-562.

Staessen, J. A.; Li, Y. and Richart, T. (2006): "Oral renin inhibitors". The Lancet, 368 (9545): 1449-1456.

Steel, R.D. and Torrie, J.H. (1960): Principles and Procedures of statistics. McGraw.Hill.Book, Company, Inc.

Taskin, E1.; Ozdogan, K.; Kunduz Kindap, E.and Dursun, N. (2014): The restoration of kidney mitochondria function by inhibition of angiotensin-II production in rats with acute 
adriamycin-induced nephrotoxicity. Ren Fail., 36(4):606-12.

Thomas, L. (2005): Renin-AngiotensinAldosterone-System (RAAS). Labor und Diagnose; 1406-24.

Uehara, T.; Watanable, H.; Itoh, F.; Inoue, S.and Koshida, H.; Nakamura, M.; Yamate, J. and Maruyama, T. (2005): Nephrotoxicity of a novel antineoplastic platinum complex, nedaplatin: a comparative study with cisplatin in rats. Arch. Toxicol, 79(8): 451-460.

Ugur, S1.; Ulu, R.; Dogukan, A.; Gurel, A.; Yigit, IP.; Gozel, N.; Aygen, B.and Ilhan, N.(2015): The Reno protective effect of curcumin in cisplatin-induced nephrotoxicity. Department of Nephrology, Medical Faculty, Firat University, Elazig, Turkey, 16:1-5.

Uzunova, V.V.; Tolekova, A.N.; Ilieva, G.S. and Trifonova, A.P. (2005): ReninAngiotensin System and Lipid Peroxidation. Bulgarian Journal of Veterinary Medicine. 1: 69-75.

Wei, Q.; Dong, G.; Yang, T;. Megyesi, J.; Price, PM.; Dong, Z. (2007): Activation and involvement of p53 in cisplatin-induced nephrotoxicity. Am J Physiol Renal Physiol 293: F1282F1291.
Woods, AE. and Ellis, RC. (1994): Laboratory histopathology, a complete reference. 1st. Ed. Churchill Livingstone. Edinburgh, Hong Kong, London, Madrid, Melbourne, Newyork, Toky.

Yoshioka, T.; Takehara, Y.; Shimatani, M.; Abe, K. and Utsumi, K. (1982): Lipid peroxidation and antioxidants in rat liver during development. The Tohoku Journal of Experimental Medicine 137:391- 400 .

Zhou,H.;Kato,A.;Miyaji,T.;Yasuda,H.;Fuji gaki,Y.;Yamamoto,T.;Yonemura,K.; Takebayashi,S.;Mineta,H.and

Hishida,A.(2006): Urinary marker for oxidative stress in kidneys in cisplaininduced acute renal failure in rats. Nephrology, dialysis, transplantation: official publication of the European Dialysis and Transplant Association European Renal Association 21,616623.

Ziori, H1.; Kyriakidis, M.; Zioris, H.; Gorgoulis, V.; Kostomit sopoulos, N.; Kittas, C.h.and Karayannakos, P. (2006): The effects of enalapril on p53 expression in left ventricular cardiomyocytes after aortic stenosis In Vivo, Biochem. Mol. Biol,20(4):45965. 
الملخص العربى

\title{
التأثير الوقائى لبعض مثبطات الرينين فى التسمم الكلوى الحاد الناتج عن بعض الادوية الاضادة

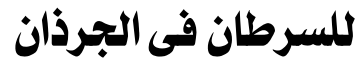

\author{
** السعيد الشربينى السعيل* ، جهاد رمضان السيل* مع شيماء احمد ابراهيه \\ *قسم الكيمياء الحيوية وكيمياء التغذية ، كلية الطب البيطرى، جامعة المنصورة، \\ ** معهُ بحوث صحة الحيوان فرع كفر الثيخ
}

تهدف هذه الاراسة الى استبيان تأثير دواء الكابتوبريل على بعض الدلالات الكيميائية فى مصل الدم فى الفئران

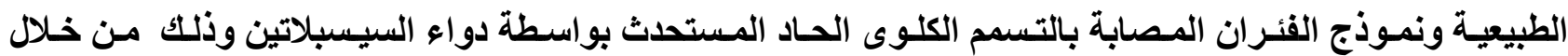

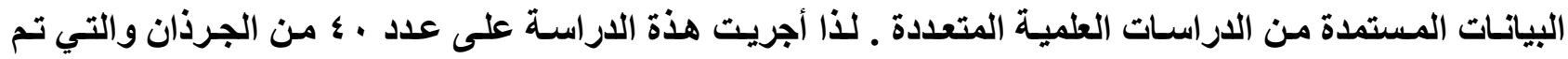

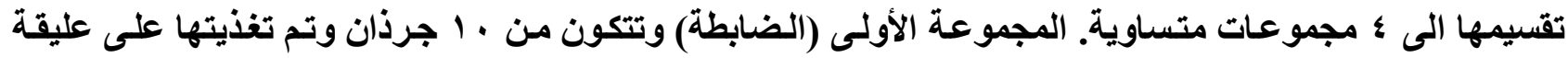

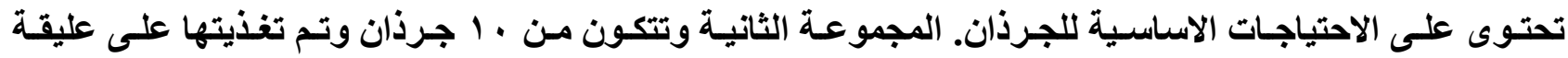

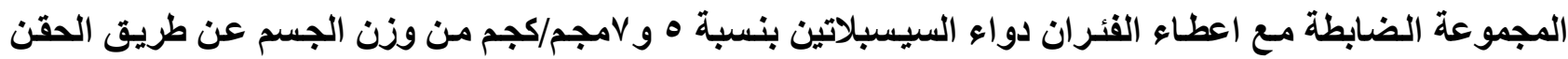

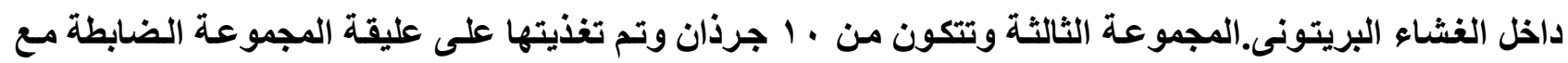

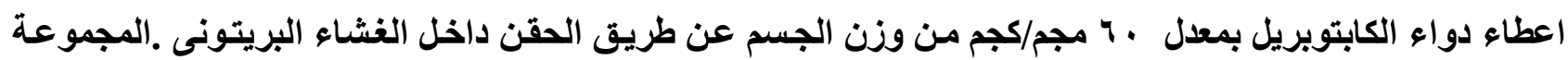

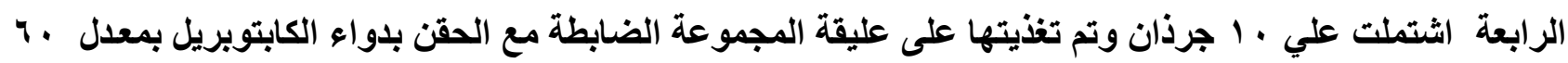
مجم/كجم من وزن الجسم عن طريق الحقن داخل الغشاء البريتونى ثم خلال ساعة يتم حقن الفئران بدواء السيسبلاتين بنسبة ه و \مجم/كجم من وزن الجسم عن طريق الحقن داخل الغثاء البريتونى لمدة شهر كامل وفى النهايـة أتضح أن

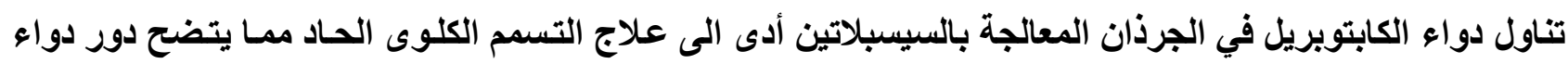

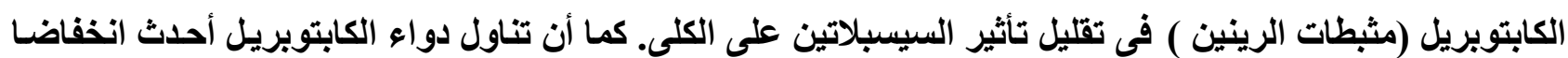

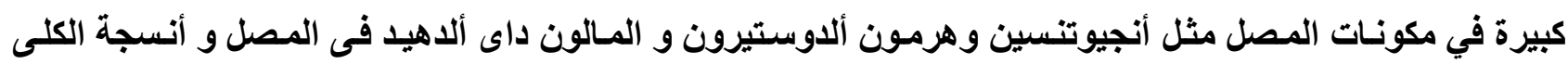
ويروتين به في الدم و أنسجة الكلى. وكذلك انخفاض غير ملحوظ في مصل الكريساتينين و نتروجين يوريـا التَّم. كمـا تسبب تناول دواء الكابتوبريل الى زيـادة كبيرة في نشاط انزيم الجلوتـاثيون المختزل في اللام و انزيم السوبر أكسيد ديسميوتاز و أنزيم كتاليزو انزيم الجلوتاثيون بروكسيديز. وتم تأكيد تلك النتائج بالفحص المهجرى للانسجة حيث وجد

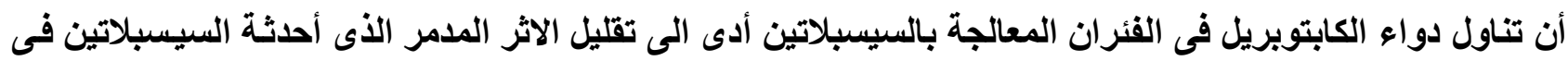

